\title{
Hybrid calcium carbonate/polymer microparticles containing silver nanoparticles as antibacterial agents
}

\author{
Maciej Długosz • Maria Bulwan • \\ Gabriela Kania • Maria Nowakowska • \\ Szczepan Zapotoczny
}

Received: 21 May 2012/ Accepted: 12 November 2012/Published online: 25 November 2012

(C) The Author(s) 2012. This article is published with open access at Springerlink.com

\begin{abstract}
We report here on synthesis and characterization of novel hybrid material consisting of silver nanoparticles (nAgs) embedded in calcium carbonate microparticles $\left(\mu-\mathrm{CaCO}_{3}\right)$ serving as carriers for sustained release. nAgs are commonly used as antimicrobial agents in many commercial products (textiles, cosmetics, and drugs). Although they are considered to be safe, their interactions with human organisms are still not fully understood; therefore it is important to apply them with caution and limit their presence in the environment. The synthesis of the new material was based on the co-precipitation of $\mathrm{CaCO}_{3}$ and $\mathrm{nAg}$ in the presence of poly(sodium 4-styrenesulfonate). Such designed system enables sustained release of $\mathrm{nAg}$ to the environment. This hybrid colloidal material $\left(\mathrm{nAg} / \mu-\mathrm{CaCO}_{3}\right)$ was characterized by microscopic and spectroscopic methods. The release of $\mathrm{nAg}$ from $\mu-\mathrm{CaCO}_{3}$ microparticles was followed in water at various $\mathrm{pH}$ values. Microbiological tests confirmed the effectiveness of these microparticles as an antibacterial agent. Importantly, the material can be stored as a dry powder and subsequently re-suspended in water without the risk of losing its
\end{abstract}

Electronic supplementary material The online version of this article (doi:10.1007/s11051-012-1313-7) contains supplementary material, which is available to authorized users.

M. Długosz - M. Bulwan · G. Kania · M. Nowakowska ·

S. Zapotoczny $(\bowtie)$

Faculty of Chemistry, Jagiellonian University, Ingardena 3, 30-060 Krakow, Poland

e-mail: zapotocz@chemia.uj.edu.pl antimicrobial activity. $\mathrm{nAg} / \mu-\mathrm{CaCO}_{3}$ was applied here to insure bacteriostatic properties of down feathers that may significantly prolong their lifetime in typical applications. Such microparticles may be also used as, e.g., components of coatings and paints protecting various surfaces against microorganism colonization.

Keywords Silver nanoparticles .

Antimicrobial agent - Calcium carbonate microparticles · Controlled release

\section{Introduction}

Silver, in the form of nanoparticles (nAg) and ions, is a common antimicrobial agent. It interacts with cell components (e.g., DNA, RNA, and ribosomal units), deactivating them and effectively stopping microbial life processes. It has been observed that $\mathrm{nAg}$ can puncture cell membranes and penetrate deep into the cell interior. This, in combination with their slow dissolution and ability to release $\mathrm{Ag}^{+}$ions, results in excellent antimicrobial activity even at nanomolar concentrations (Sondi and SalopekSondi 2004; Yamanaka et al. 2005; Feng et al. 2000; Lok et al. 2006). $\mathrm{nAg}$ are effective agents even against multidrug-resistant strains (Lara et al. 2009). These exceptional properties of $\mathrm{nAg}$ resulted in wide range of their practical applications. They have been applied as an antibiotic additive in the production of biomedical devices (Roe et al. 2008; Cao and Liu 2010), wound dressings (Nguyen et al. 2011; Tian et al. 2007), water (Lv et al. 
2009; Jain and Pradeep 2005) and air (Yoon et al. 2008) filters, textiles (Tang et al. 2011; Lee et al. 2003), food packaging (Tankhiwale and Bajpai 2009), cosmetics (Kokura et al. 2010), and drugs (Shahverdi et al. 2007).

However, it has been shown that the growing number of application of nAg may lead to the build up of silver concentrations in the environment to such a level at which it can not only cause health problems in humans (Kim et al. 2011) but also may be harmful for various components of the environment (Lee et al. 2007) and may even affect the industrially relevant processes (Brar et al. 2010). Therefore, it is important to use $\mathrm{nAg}$ rationally and to control their release to the environment. The current paper presents our approach to this problem. We have proposed to embed nAg into the biologically inert calcium carbonate microparticle $\left(\mu-\mathrm{CaCO}_{3}\right)$ matrix (Lei et al. 2006). Several other attempts to immobilize $\mathrm{nAg}$ with polymers have been already proposed (Benetti et al. 2010). They include immobilization on glass and silica (Cai et al. 2001; Lv et al. 2008), on natural fibers (Tang et al. 2011; Lee et al. 2003), on hydroxyapatite (Nirmala et al. 2011), and even on the surface of steel (Chen et al. 2010). However, to the best of our knowledge, the colloidal system containing silver nanoparticles trapped inside calcium carbonate microparticles $\left(\mathrm{nAg} / \mu-\mathrm{CaCO}_{3}\right)$ has not been fabricated so far. Such application of $\mu-\mathrm{CaCO}_{3}$ microparticles is in line with their most common usage as sacrificial templates for fabrication of hollow polymeric microcapsules (Volodkin et al. 2004) carrying various organic molecules such as low molecular weight drugs (Tong et al. 2011) or proteins (Petrov et al. 2005). The approach proposed here should insure long-lasting antibacterial activity of the material due to the sustained release of silver on one hand and limit the contact of $\mathrm{nAg}$ with human body on the other. In addition, this material can be easily stored as a water dispersible powder and its surface charge can be readily modified for various applications. This new material may find applications as a component of coatings and paints protecting the surfaces against microorganism colonization.

\section{Materials and methods}

\section{Materials}

Poly(sodium 4-styrenesulfonate) (PSS, Aldrich, $M_{\mathrm{w}} \approx$ $70,000 \mathrm{~g} / \mathrm{mol}$ ), poly(allylamine hydrochloride) (PAH,
Aldrich, $\left.M_{\mathrm{w}} \approx 15,000 \mathrm{~g} / \mathrm{mol}\right)$. Silver nitrate, trisodium citrate, calcium nitrate, sodium carbonate, acetone, sulfuric acid (98\%), nitric acid (65\%), hydrogen peroxide $(30 \%)$, ethylenediaminetetraacetic acid (EDTA), disodium phosphate, and citric acid were obtained from POCH Gliwice, Poland. Single-side polished silicon plates were obtained from the Institute of Electronic Materials Technology (Warsaw, Poland) and cleaned before the use in freshly prepared "piranha solution" (a mixture of $30 \%$ solution of $\mathrm{H}_{2} \mathrm{O}_{2}$ and concentrated $\mathrm{H}_{2} \mathrm{SO}_{4}$ in 1:3 ratio) (Caution: "piranha solution" should be handled with extreme care!). Deionized water was used in all experiments. Buffers were prepared by mixing appropriate amounts of $0.1 \mathrm{M}$ citric acid and $0.2 \mathrm{Na}_{2} \mathrm{HPO}_{4}$.

\section{Procedures}

Synthesis of $n \mathrm{Ag} / \mu-\mathrm{CaCO}_{3}$ material and its surface modification

In the first step, nAg were obtained by modified Lee and Meisel method (1982). Shortly, $45 \mathrm{mg}$ of silver nitrate was dissolved in $250 \mathrm{ml}$ of water and then $5 \mathrm{ml}$ of $1 \%$ trisodium citrate was added. The reaction mixture was placed in an ultrasonic bath and heated to $75{ }^{\circ} \mathrm{C}$ for $60 \mathrm{~min}$. In the second step, $20 \mathrm{ml}$ of the obtained $\mathrm{nAg}$ colloid was simultaneously mixed with $50 \mathrm{ml}$ of $0.03 \mathrm{M} \mathrm{Ca}\left(\mathrm{NO}_{3}\right)$ solution and $50 \mathrm{ml}$ of 0.03 $\mathrm{Na}_{2} \mathrm{CO}_{3}$ with addition of PSS $(4.8 \mathrm{~g} / \mathrm{l})$. The mixture was sonicated for $5 \mathrm{~min}$ at $25^{\circ} \mathrm{C}$. The obtained white colloid was washed with deionized water and centrifuged at 4,000 rpm for $5 \mathrm{~min}$ to remove excess of silver. The washing process was repeated three times and the obtained product was dried under vacuum.

For surface modification, $\mathrm{nAg} / \mu-\mathrm{CaCO}_{3}$ particles were dispersed in $\mathrm{PAH}$ solution $(1 \mathrm{~g} / 1$ in $0.1 \mathrm{M} \mathrm{NaCl})$ and stirred for $15 \mathrm{~min}$. They were subsequently centrifuged and washed with deionized water.

\section{Characterization of $n A g$}

$\mathrm{UV}-\mathrm{Vis}$ spectrum of the obtained $\mathrm{nAg}$ suspension was acquired. The size of the nanoparticles was determined by atomic force microscopy (AFM, Picoforce, Bruker, USA) working in tapping mode. Standard silicon cantilevers (Bruker) with nominal spring constants equal to $40 \mathrm{~N} / \mathrm{m}$ were used for the measurements. For 
that purpose, a silicon plate was first immersed in PAH solution $(1 \mathrm{~g} / 1$ in $0.1 \mathrm{M} \mathrm{NaCl})$ and sonicated for $5 \mathrm{~min}$. The plate was subsequently rinsed with deionized water and dried under stream of argon. A drop of the colloidal suspension of nAg was deposited on such prepared silicon support and left for drying before the imaging.

\section{Characterization of $n \mathrm{Ag} / \mu-\mathrm{CaCO}_{3}$ material}

Scanning electron microscopy images were obtained for $\mathrm{nAg} / \mu-\mathrm{CaCO}_{3}$ using Hitachi $\mathrm{S}-4700$ microscope with field emission. The samples were coated with sputtered gold layer before imaging.

To check if silver in the form of nanoparticles is embedded in $\mu-\mathrm{CaCO}_{3}$, the matrix was dissolved in $0.2 \mathrm{M}$ EDTA and the UV-Vis spectrum of the obtained solution was measured.

Total content of silver in $\mathrm{nAg} / \mu-\mathrm{CaCO}_{3}$ was measured by atomic absorption spectrometry (AAS) using PerkinElmer Aanalyst 300 instrument with flame atomizer. The samples were transferred into solution by dissolving in $0.12 \mathrm{M} \mathrm{HNO}_{3}$. The appropriate calibration procedure was performed using samples of $\mathrm{AgNO}_{3}$ in $0.12 \mathrm{M} \mathrm{HNO}_{3}$. The measurements were also performed for the starting $\mathrm{nAg}$ dispersion and supernatant collected after centrifugation of the reaction mixture.

\section{Accelerated release of $n \mathrm{Ag}$ from $n \mathrm{Ag} / \mu-\mathrm{CaCO}_{3}$}

The samples of $\mathrm{nAg} / \mu-\mathrm{CaCO}_{3}(440 \mathrm{mg})$ were dispersed in $8 \mathrm{ml}$ of the appropriate buffer solutions with $\mathrm{pH}$ values equal to 5.4 and 6.8. They were vigorously stirred for a given period of time and then centrifuged. Supernatants were collected for AAS analyses and the next portions of fresh buffer solutions were added each time. The procedure was continued for 14 days.

\section{Treatment of down feathers}

The $\mathrm{nAg} / \mu-\mathrm{CaCO}_{3}$ were introduced to the feathers by their immersion in the $0.6 \%$ dispersion for $30 \mathrm{~min}$. Then the feathers were dried under a stream of argon. The samples were investigated by optical microscopy (Nikon Eclipse LV 100) and SEM (Hitachi S-4700 s microscope) to confirm the attachment of $\mathrm{nAg} / \mu$ $\mathrm{CaCO}_{3}$ to the feathers.

\section{In vitro antimicrobial activity}

To prove the antimicrobial activity of the obtained materials, the microbiological tests were carried out. Various bacterial species were placed in physiological salt media to which equal amounts of $n \mathrm{Ag} / \mu-\mathrm{CaCO}_{3}$ dispersion were added and left for $24 \mathrm{~h}$. The bacterial and fungal species were naturally occurring skin microbes and were acquired from several healthy people. The microbial concentration was expressed in McFarland scale $\left({ }^{\circ} \mathrm{McF}\right)$ based on the nephelometric measurements. One McFarland scale is equivalent to turbidity of standard $\mathrm{BaSO}_{4}$ colloid in concentration of $4.80 \times 10^{-5} \mathrm{M} . \mathrm{nAg} / \mu-\mathrm{CaCO}_{3}$ as well as down $/ \mathrm{nAg} /$ $\mu-\mathrm{CaCO}_{3}$ and sole $\mathrm{nAg}$ dispersion systems were tested. The initial turbidity was acquired before the addition of the antimicrobial materials or down feathers. The concentration of the antimicrobial hybrid material was kept constant in each test and it was allowed to sediment before the measurements of the microbial concentration. The feathers, after the incubation, were removed from the dispersion. In the case of sole $\mathrm{nAg}$ dispersion, the total turbidity (with contribution of $\mathrm{nAg}$ ) was measured. The respective microbial concentrations were taken as mean values of a few measurements.

\section{Results and discussion}

Successful two-step synthesis of novel antimicrobial material consisting of $\mathrm{nAg}$ embedded in $\mu-\mathrm{CaCO}_{3}$ microparticle matrix was achieved. The $\mathrm{nAg}$ were obtained by modified method developed earlier by Lee and Meisel. The method is based on the reduction of silver nitrate by sodium citrate in hot water (Lee and Meisel 1982). It is important to note that the process is carried out in aqueous medium and with the use of low toxicity reagents. Citrate ions play also a second function-they protect Ag nanoparticles form aggregation, thus keeping their size relatively small. This is very important considering the fact that the antimicrobial activity of $\mathrm{nAg}$ rises significantly with the reduction of their sizes (Panáček et al. 2006).

In a current study, the method was modified by the application of ultrasonic waves and lowering the reaction temperature to $75^{\circ} \mathrm{C}$ which resulted in formation of fine (30-50 nm) and more monodisperse nAg as shown by AFM (Fig. 1). The surface charge of 
Fig. 1 a AFM image and $\mathbf{b}$ the corresponding cross section of the obtained nAg adsorbed on positively charged layer of PAH on silicon
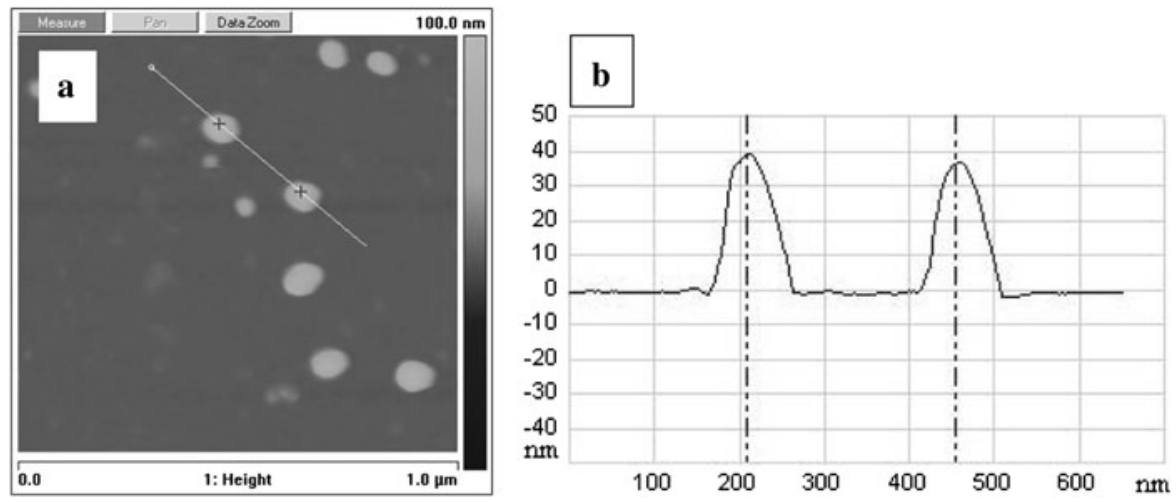

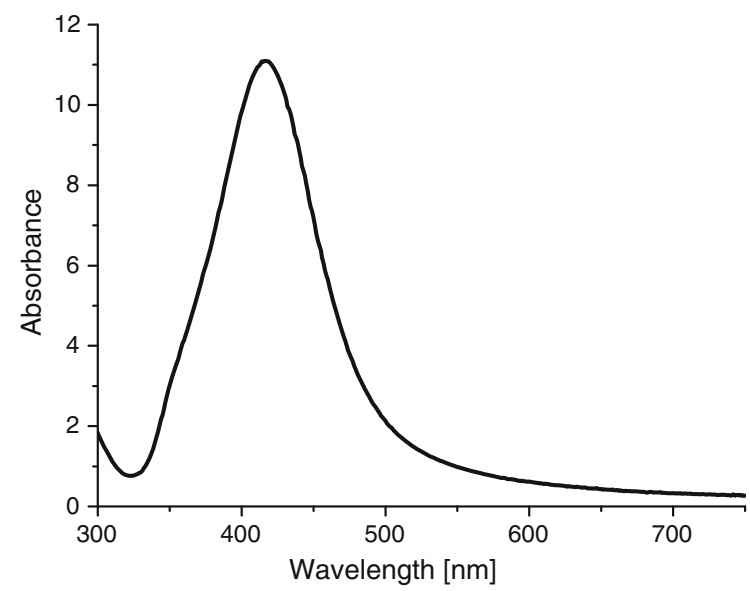

Fig. 2 UV-Vis absorption spectrum of the obtained $\mathrm{nAg}$ suspension

the synthesized $\mathrm{nAg}$ is negative due to the presence of citrate ions adsorbed. This was confirmed by the observation of strong adsorption of $\mathrm{nAg}$ on $\mathrm{PAH}$ covered silica plate characterized by positive surface charge (Fig. 1) and lack of adsorption on negatively charged, unmodified silica plates. The obtained colloidal suspension was also characterized spectroscopically. Green color of $\mathrm{nAg}$ colloid and its characteristic UV-Vis spectrum with the maximum around $420 \mathrm{~nm}$ (Fig. 2) originates from localized surface plasmon resonance of these metallic nanostructures (Kelly et al. 2002).

The obtained nanoparticles were then embedded into $\mu-\mathrm{CaCO}_{3}$ matrix by co-precipitation in the presence of the polyelectrolyte (PSS) resulting in the formation of $\mathrm{nAg} / \mu-\mathrm{CaCO}_{3}$ colloidal material. The mechanism of $\mu-\mathrm{CaCO}_{3}$ formation involves the creation of nanometer-sized crystallites at the first stage which later aggregate to form micrometer-sized superstructures. $\mathrm{nAg}$ introduced during the co-precipitation process can adsorb on such nanocrystallites due to the electrostatic interactions before their aggregation. In such a way, the embedded nAg stay firmly attached inside the $\mathrm{CaCO}_{3}$ matrix and are not prone to fast releasing through the pores of $\mu-\mathrm{CaCO}_{3}$ (Petrov et al. 2005). SEM analyses have proven that the obtained spherical microparticles are practically monodisperse with the diameter around $2 \mu \mathrm{m}$ (Fig. 3). This was
Fig. 3 SEM images of $\mathrm{nAg} / \mu-\mathrm{CaCO}_{3}$ at different magnifications
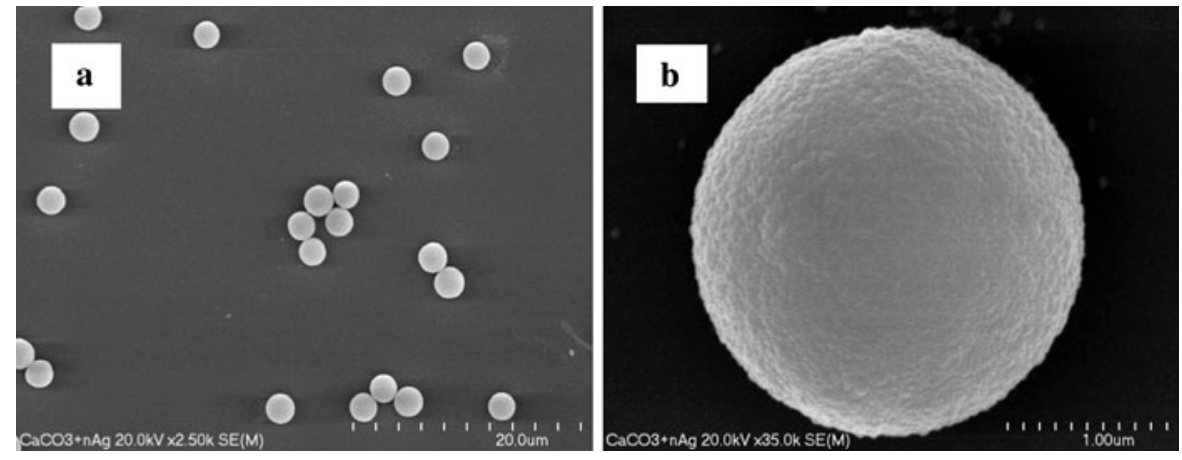


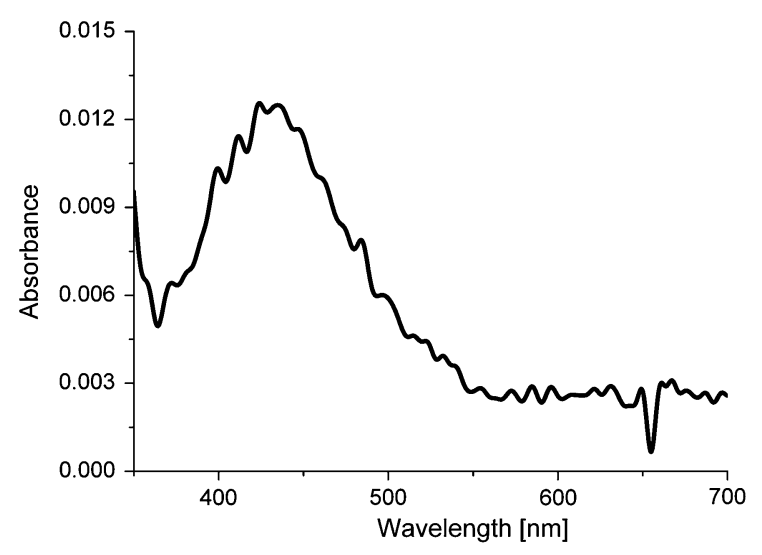

Fig. $4 \mathrm{UV}-\mathrm{Vis}$ spectrum of $\mathrm{nAg} / \mu-\mathrm{CaCO}_{3}$ dispersion after the dissolution of the carbonate matrix using EDTA

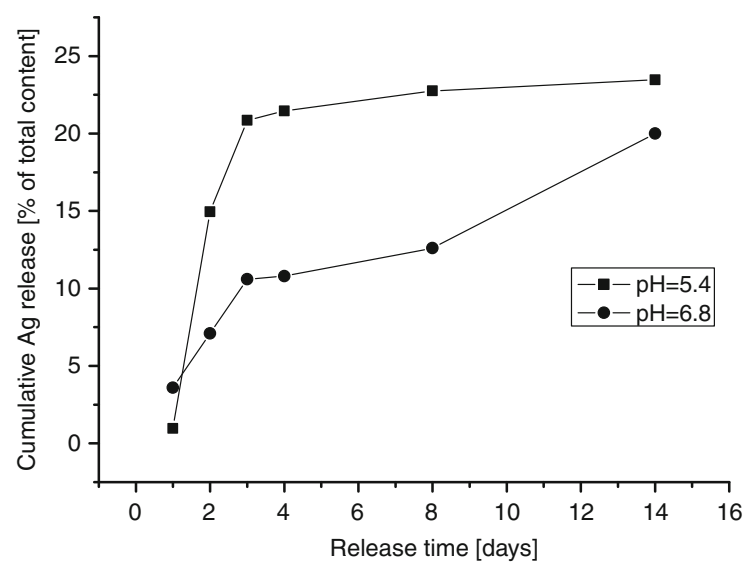

Fig. 5 Sustained release of silver into buffer solutions

achieved by the addition of PSS anionic polyelectrolyte and application of ultrasound agitation. To prove the presence of $\mathrm{nAg}$ in the $\mathrm{nAg} / \mu-\mathrm{CaCO}_{3}$, the carbonate matrix was dissolved using 0.2 M EDTA and then the UV/Vis spectrum of such solution was acquired
(Fig. 4), in which characteristic peak for $\mathrm{nAg}(420 \mathrm{~nm})$ was observed. This experiment, however, cannot be used to determine the content of silver because dissolution was not complete and $\mathrm{Ag}^{+}$was only partially chelated by EDTA. The total silver content in nanoparticles was estimated by AAS. It was found that about $21 \%$ of silver originally present in solution was successfully embedded into $\mu-\mathrm{CaCO}_{3}$ matrix, thus making $0.015 \%$ mass of the whole material. Such content of $\mathrm{nAg}$ is more than enough to kill bacteria efficiently even if the silver would be present only in the form of $\mathrm{Ag}^{+}$ions (Lok et al. 2006). In addition, EDS analysis of the milled microparticles was performed confirming the presence of embedded $\mathrm{nAg}$ in $\mathrm{CaCO}_{3}$ matrix (see Supplementary Materials).

Sustained release of silver into the buffer solutions was then studied. It has been proven that silver is firmly embedded into microcapsules and can be slowly released over long period of time (Fig. 5). More rapid release of silver in the buffer with lower $\mathrm{pH}$ indicates a significant contribution of $\mathrm{CaCO}_{3}$ dissolution to the releasing process. The initial ca. $25 \%$ release of silver can be attributed to the presence of the most loosely attached fraction of nanoparticles. Further release of $\mathrm{nAg}$, which are deeply embedded and/or firmly attached to the matrix should be much slower and most likely can occur with disintegration or dissolution of the microparticles (Petrov et al. 2005).

Surface of $\mathrm{nAg} / \mu-\mathrm{CaCO}_{3}$ microparticles was later modified by the adsorption of positively charged polyelectrolytes like PAH. The modified material, with positive surface charge, was much easier adsorbed on the negatively charged mica than unmodified material as it can be observed in the optical microscopy images (Fig. 6).

Antimicrobial activity of the $\mathrm{nAg} / \mu-\mathrm{CaCO}_{3}$ microparticles was then tested. High quality down feathers
Fig. 6 Optical microscopy images of $\mathrm{nAg} / \mu-\mathrm{CaCO}_{3}$ (a) and $\mathrm{nAg} / \mu$ $\mathrm{CaCO}_{3}$ modified with PAH layer (b) on mica surface
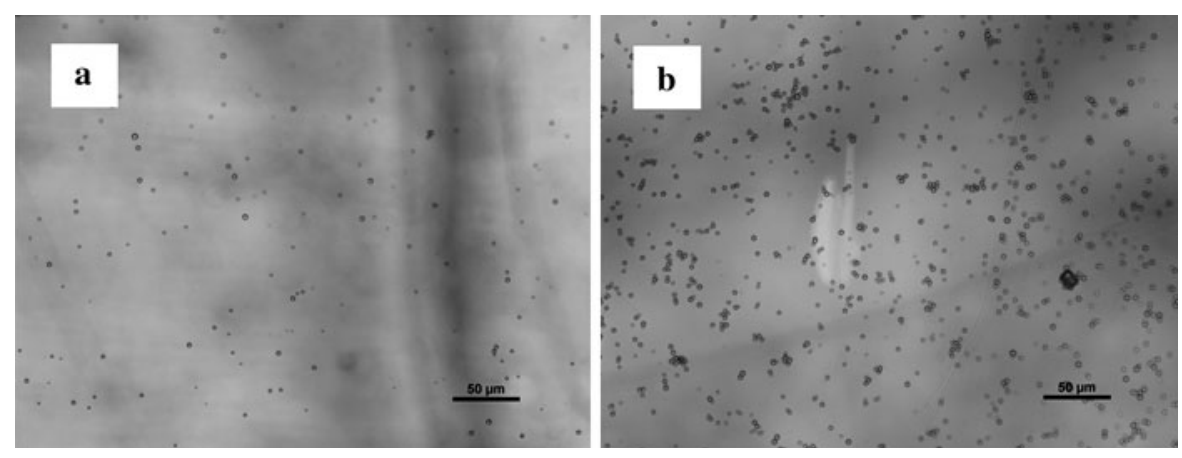
Fig. 7 Optical microscopy images of a native feathers, b feathers covered with $\mathrm{nAg} / \mu-\mathrm{CaCO}_{3}$ and SEM pictures of c native feathers, d feathers covered with $\mathrm{nAg} / \mu-\mathrm{CaCO}_{3}$
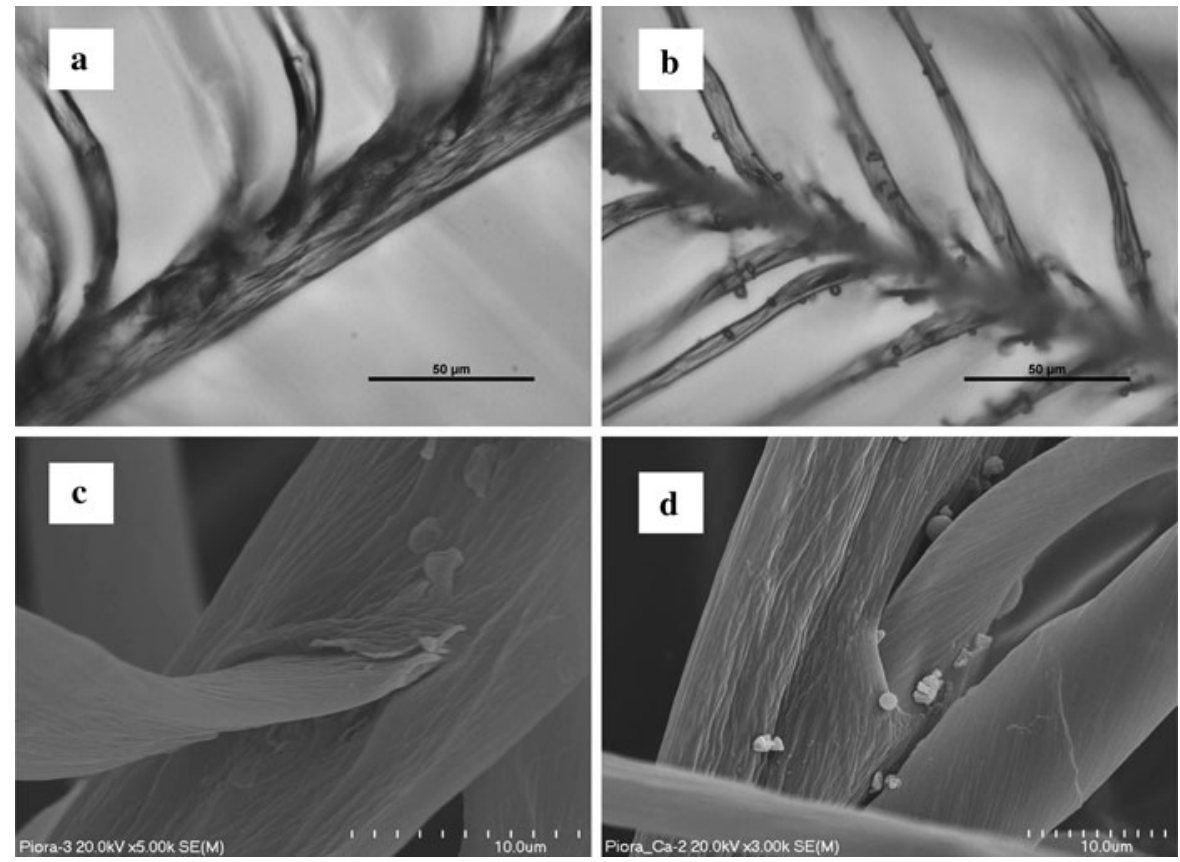

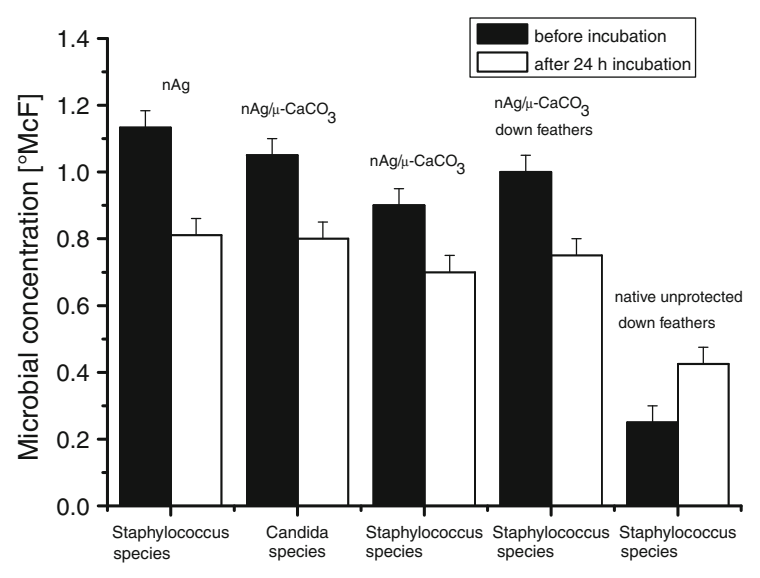

Fig. 8 The results of microbial tests for different species. Above each column, the antimicrobial additives are listed and below are the names of employed microbial species

were immersed in $\mathrm{nAg} / \mu-\mathrm{CaCO}_{3}$ aqueous dispersion. Numerous microparticles were attached to feathers successfully, as observed using optical and electron scanning microscopes (Fig. 7). It is worth noting that the microparticles were so firmly attached to the feathers that even high vacuum conditions used during SEM analyses did not remove them.

The $\mathrm{nAg} / \mu-\mathrm{CaCO}_{3}$ material itself as well as the feathers covered with this agent limited the microbial proliferation. After 24-h incubation, there was a clear decrease in microbial concentration in both cases (Fig. 8). For the comparison, dispersion of sole $\mathrm{nAg}$ was used showing similar antimicrobial activity. In contrast, the native unprotected feathers serving as a nutrient accelerated the microbial growth (Fig. 8). Thus, it can be concluded that $\mathrm{nAg} / \mu-\mathrm{CaCO}_{3}$ retains its antimicrobial activity and application of $\mathrm{nAg}$ in such a form may limit the contact of the nanoparticles with human body that is of importance considering their long term influence.

\section{Conclusion}

Novel hybrid antibacterial microparticles, $\mathrm{nAg} / \mu-\mathrm{CaCO}_{3}$, consisting of $\mathrm{nAg}$ incorporated into calcium carbonate/ polymer microparticles $\left(\mu-\mathrm{CaCO}_{3}\right)$, were obtained in a simple synthetic procedure carried out in aqueous environment and involving non-toxic compounds. Originally prepared $\mathrm{nAg}$ with diameters in the range of 30-50 nm were used in co-precipitation process which results in the formation of $\mathrm{nAg} / \mu-\mathrm{CaCO}_{3}$ spherical microparticles. The obtained material enabled sustained release of $\mathrm{nAg}$, thus limiting the possible environmental problems. Surface charge of the matrix can be readily modified by adsorption of polycations expanding potential applications of $\mathrm{nAg} / \mu-\mathrm{CaCO}_{3}$ to 
various surfaces. This novel material can be safely stored as a white powder without the risk of losing its antimicrobial activity, in contrast to the sole $\mathrm{nAg}$ which tend to aggregate when dried. $\mathrm{nAg} / \mu-\mathrm{CaCO}_{3}$ system was shown to be efficient in limiting the proliferation of microorganisms that makes it suitable for applications involving contact with human skin. As an example, the successful application of $\mathrm{nAg} /$ $\mu-\mathrm{CaCO}_{3}$ for the protection of down feathers against microorganisms was presented.

Acknowledgments The authors would like to acknowledge the financial support of EU Programme "Doctus" MPC.ZS.4110$63.4 / 2008$. The research was carried out with the equipment purchased thanks to the financial support of the European Regional Development Fund in the framework of the Polish Innovation Economy Operational Program (Contract No. POIG. 02.01.00-12-023/08). The P2M program from the ESF is also gratefully acknowledged.

Open Access This article is distributed under the terms of the Creative Commons Attribution License which permits any use, distribution, and reproduction in any medium, provided the original author(s) and the source are credited.

\section{References}

Benetti EM, Sui X, Zapotoczny S, Vancso GJ (2010) Surfacegrafted gel-brush/metal nanoparticle hybrids. Adv Funct Mater 20(6):939-944. doi:10.1002/adfm.200902114

Brar SK, Verma M, Tyagi RD, Surampalli RY (2010) Engineered nanoparticles in wastewater and wastewater sludgeevidence and impacts. Waste Manag 30(3):504-520. doi: 10.1016/j.wasman.2009.10.012

Cai W, Hofmeister H, Rainer T, Chen W (2001) Optical properties of $\mathrm{Ag}$ and $\mathrm{Au}$ nanoparticles dispersed within the pores of monolithic mesoporous silica. J Nanopart Res 3(5):441-451. doi:10.1023/a:1012537817570

Cao H, Liu X (2010) Silver nanoparticles-modified films versus biomedical device-associated infections. Wiley Interdiscip Rev 2(6):670-684. doi:10.1002/wnan.113

Chen L, Zheng L, Lv Y, Liu H, Wang G, Ren N, Liu D, Wang J, Boughton RI (2010) Chemical assembly of silver nanoparticles on stainless steel for antimicrobial applications. Surf Coat Technol 204(23):3871-3875. doi:10.1016/j.surfcoat. 2010.05.003

Feng QL, Wu J, Chen GQ, Cui FZ, Kim TN, Kim JO (2000) A mechanistic study of the antibacterial effect of silver ions on Escherichia coli and Staphylococcus aureus. J Biomed Mater Res 52(4):662-668

Jain P, Pradeep T (2005) Potential of silver nanoparticle-coated polyurethane foam as an antibacterial water filter. Biotechnol Bioeng 90(1):59-63. doi:10.1002/bit.20368

Kelly KL, Coronado E, Zhao LL, Schatz GC (2002) The optical properties of metal nanoparticles: the influence of size, shape, and dielectric environment. J Phys Chem B 107(3): 668-677. doi:10.1021/jp026731y
Kim HR, Kim MJ, Lee SY, Oh SM, Chung KH (2011) Genotoxic effects of silver nanoparticles stimulated by oxidative stress in human normal bronchial epithelial (BEAS-2B) cells. Mutat Res 726(2):129-135. doi:10.1016/j.mrgentox. 2011.08.008

Kokura S, Handa O, Takagi T, Ishikawa T, Naito Y, Yoshikawa $\mathrm{T}$ (2010) Silver nanoparticles as a safe preservative for use in cosmetics. Nanomed Nanotechnol Biol Med 6(4):570-574. doi:10.1016/j.nano.2009.12.002

Lara HH, Ayala-Núñez NV, Ixtepan Turrent L, Rodríguez Padilla C (2009) Bactericidal effect of silver nanoparticles against multidrug-resistant bacteria. World J Microbiol Biotechnol 26(4):615-621. doi:10.1007/s11274-009-0211-3

Lee PC, Meisel D (1982) Adsorption and surface-enhanced Raman of dyes on silver and gold sols. J Phys Chem 86(17): 3391-3395. doi:10.1021/j100214a025

Lee HJ, Yeo SY, Jeong SH (2003) Antibacterial effect of nanosized silver colloidal solution on textile fabrics. J Mater Sci 38(10):2199-2204. doi:10.1023/a:1023736416361

Lee KJ, Nallathamby PD, Browning LM, Osgood CJ, Xu XN (2007) In vivo imaging of transport and biocompatibility of single silver nanoparticles in early development of zebrafish embryos. ACS Nano 1(2):133-143. doi:10.1021/nn $700048 y$

Lei M, Tang WH, Cao LZ, Li PG, Yu JG (2006) Effects of poly (sodium 4-styrene-sulfonate) on morphology of calcium carbonate particles. J Cryst Growth 294(2):358-366. doi: 10.1016/j.jcrysgro.2006.06.029

Lok CN, Ho CM, Chen R, He QY, Yu WY, Sun H, Tam PK, Chiu JF, Che CM (2006) Proteomic analysis of the mode of antibacterial action of silver nanoparticles. J Proteome Res 5(4):916-924. doi:10.1021/pr0504079

Lv Y, Liu H, Wang Z, Hao L, Liu J, Wang Y, Du G, Liu D, Zhan J, Wang J (2008) Antibiotic glass slide coated with silver nanoparticles and its antimicrobial capabilities. Polym Adv Technol 19(11):1455-1460. doi:10.1002/pat.1138

Lv Y, Liu H, Wang Z, Liu S, Hao L, Sang Y, Liu D, Wang J, Boughton RI (2009) Silver nanoparticle-decorated porous ceramic composite for water treatment. J Membr Sci 331(1-2):50-56. doi:10.1016/j.memsci.2009.01.007

Nguyen TH, Kim YH, Song HY, Lee BT (2011) Nano Ag loaded PVA nano-fibrous mats for skin applications. J Biomed Mater Res B 96(2):225-233. doi:10.1002/jbm.b.31756

Nirmala R, Sheikh F, Kanjwal M, Lee J, Park S-J, Navamathavan R, Kim H (2011) Synthesis and characterization of bovine femur bone hydroxyapatite containing silver nanoparticles for the biomedical applications. J Nanopart Res 13(5):1917-1927. doi:10.1007/s11051-010-9944-Z

Panáček A, Kvítek L, Prucek R, Kolár M, Večeřová R, Pizúrová N, Sharma VK, Nevěčná T, Zbořil R (2006) Silver colloid nanoparticles: synthesis, characterization, and their antibacterial activity. J Phys Chem B 110(33):16248-16253. doi:10.1021/jp063826h

Petrov AI, Volodkin DV, Sukhorukov GB (2005) Protein-calcium carbonate coprecipitation: a tool for protein encapsulation. Biotechnol Progr 21(3):918-925. doi:10.1021/ Bp0495825

Roe D, Karandikar B, Bonn-Savage N, Gibbins B, Roullet JB (2008) Antimicrobial surface functionalization of plastic catheters by silver nanoparticles. J Antimicrob Chemother 61(4):869-876. doi:10.1093/jac/dkn034 
Shahverdi AR, Fakhimi A, Shahverdi HR, Minaian S (2007) Synthesis and effect of silver nanoparticles on the antibacterial activity of different antibiotics against Staphylococcus aureus and Escherichia coli. Nanomed Nanotechnol Biol Med 3(2):168-171. doi:10.1016/j.nano.2007.02.001

Sondi I, Salopek-Sondi B (2004) Silver nanoparticles as antimicrobial agent: a case study on E. coli as a model for Gram-negative bacteria. J Colloid Interface Sci 275(1): 177-182. doi:10.1016/j.jcis.2004.02.012

Tang B, Wang J, Xu S, Afrin T, Xu W, Sun L, Wang X (2011) Application of anisotropic silver nanoparticles: multifunctionalization of wool fabric. J Colloid Interface Sci 356(2):513-518. doi:10.1016/j.jcis.2011.01.054

Tankhiwale R, Bajpai SK (2009) Graft copolymerization onto cellulose-based filter paper and its further development as silver nanoparticles loaded antibacterial food-packaging material. Colloids Surf B 69(2):164-168. doi:10.1016/ j.colsurfb.2008.11.004

Tian J, Wong KK, Ho CM, Lok CN, Yu WY, Che CM, Chiu JF, Tam PK (2007) Topical delivery of silver nanoparticles promotes wound healing. ChemMedChem 2(1):129-136. doi:10.1002/cmdc. 200600171

Tong W, She S, Xie L, Gao C (2011) High efficient loading and controlled release of low-molecular-weight drugs by combination of spontaneous deposition and heat-induced shrinkage of multilayer capsules. Soft Matter 7(18):8258-8265

Volodkin DV, Petrov AI, Prevot M, Sukhorukov GB (2004) Matrix polyelectrolyte microcapsules: new system for macromolecule encapsulation. Langmuir 20(8):3398-3406

Yamanaka M, Hara K, Kudo J (2005) Bactericidal actions of a silver ion solution on Escherichia coli, studied by energyfiltering transmission electron microscopy and proteomic analysis. Appl Environ Microbiol 71(11):7589-7593. doi: 10.1128/AEM.71.11.7589-7593.2005

Yoon KY, Byeon JH, Park CW, Hwang J (2008) Antimicrobial effect of silver particles on bacterial contamination of activated carbon fibers. Environ Sci Technol 42(4): 1251-1255 